\title{
Occupational Hazards, Safety and Hygienic Practices among Timber Workers in a South Eastern State, Nigeria
}

\author{
Kevin C. Diwe1, Chukwuma B. Duru1, Anthony C. Iwu' ${ }^{2 *}$, Irene A. Merenu', \\ Kenechi A. Uwakwe1, Uche R. Oluoha², Tope B. Ogunniyan³, \\ Ugochukwu C. Madubueze ${ }^{4}$, Ikechi Ohale² \\ ${ }^{1}$ Department of Community Medicine, Imo State University, Owerri, Nigeria \\ ${ }^{2}$ Department of Community Medicine, Imo State University Teaching Hospital, Orlu, Nigeria \\ ${ }^{3}$ Department of Community Medicine, University College Hospital, Ibadan, Nigeria \\ ${ }^{4}$ Department of Community Medicine, Federal Teaching Hospital, Abakaliki, Nigeria \\ Email: "iwuchinedu@yahoo.com
}

Received 4 August 2016; accepted 19 August 2016; published 22 August 2016

Copyright (C) 2016 by authors and Scientific Research Publishing Inc.

This work is licensed under the Creative Commons Attribution International License (CC BY). http://creativecommons.org/licenses/by/4.0/

(c) (i) Open Access

\section{Abstract}

Background: Timber workers, especially in developing countries, are faced with challenges of prevention and control of work place hazards and illnesses. Objective: To determine the awareness of occupational hazards, effects, safety and hygienic practices among timber workers in a South Eastern State in Nigeria. Methods: A cross sectional descriptive design that used the total population of timber workers involved in the processing and marketing of wood in three major timber markets in a South Eastern State in Nigeria. Data was collected using a pretested semistructured questionnaire. Descriptive analyses were done with frequencies and summary statistics. Results: The majority of the respondents were aware of the hazardous nature of wood dust (96\%) and their main source of awareness was from personal experiences (55\%). In spite of the fact that the predominant hazard effects in the majority were nose, throat irritation and cough (33\%), the majority were of the opinion that the respirator was not important. Only $13 \%$ of the respondents that use personal protective equipment (PPE) always use them and the main reason for not using PPE is forgetfulness (38\%). Proper hygiene and sanitation was poorly practiced, as all respondents indiscriminately disposed of waste wood $(100 \%)$ and about one third $(33 \%)$ did not have a bath after work each day. Conclusion: Timber workers in our environment are faced with increased risks of diseases, accidents and challenges of protection and safety. As a consequence, there is a need for proper education and enforcement of consistent use of the different protective devices.

*Corresponding author.

How to cite this paper: Diwe, K.C., Duru, C.B., Iwu, A.C., Merenu, I.A., Uwakwe, K.A., Oluoha, U.R., Ogunniyan, T.B., Madubueze, U.C. and Ohale, I. (2016) Occupational Hazards, Safety and Hygienic Practices among Timber Workers in a South Eastern State, Nigeria. Occupational Diseases and Environmental Medicine, 4, 63-71.

http://dx.doi.org/10.4236/odem.2016.43008 


\section{Keywords}

\section{Knowledge, Attitude, Practice, Occupational Hazard, Timber Worker, Imo, Nigeria}

\section{Introduction}

Occupational hazard is a risk an individual is exposed to at the workplace, and during work periods, they may be exposed to biological agents, chemical and physical factors and ergonomic conditions, which predispose the individual to occupational diseases with a variety of health effects [1]-[3]. This appears to affect a considerable number of people in a variety of jobs and indirectly impact on the economy especially in developing countries where individuals take for granted the health and safety concerns associated with work due to lack of awareness and fundamental understanding of the interactions between work and health [3]-[5].

According to World Health Organization (WHO), there are about 250 million cases of occupational injuries and illnesses occurring annually worldwide, with prevalence studies from Botswana, Zimbabwe, Zambia, Ghana and Nigeria suggesting that there is a high occurrence of occupational disease in Africa [6]-[10]. Though in Nigeria, there appears to be an increase in work related injuries and illnesses, the records of occupational diseases with relevant Government agencies are poor due to inadequate reporting [11]-[13].

The timber workers are no exception to the occurrence of occupational injuries and illnesses. They operate in clusters of privately owned small scale ventures associated with apprenticeship training. Their work involves shaping, cutting. processing and marketing of wood and so has a high risk of wood-dust exposure with negative health effects [14]. It is a source of livelihood for many Nigerians, who are usually located around timber sheds with no form of organized occupational health and safety service. As a consequence, they are at an increased risk of occupational hazards and illnesses, and as such, preventing, reducing or keeping exposures within safe limits are important to the maintenance of a healthy work force.

The main material for timber workers is wood, which is classified as either hardwood or softwood depending on the type of trees they are cut from. A significant difference between the classes of wood exists with respect to the health effect of the dust created during handling, as high exposure to the dust of hardwoods has been reported to cause nasal cancer [14].

Wood dust, regulated as a nuisance dust by the United States Occupational Safety and Health Administration (OSHA), is recognized as a confirmed human carcinogen and as a result, the American Conference of Governmental Industrial Hygienists (ACGIH) recommends an exposure limit of 1 milligram per cubic meter for hardwoods and 5 milligram per cubic meter for softwoods. Furthermore, other adverse health effects associated with wood dust include dermatitis, allergic and non-allergic respiratory effects [14].

However, in terms of Government regulation, there is little or no attention given to the control of occupational hazards and its health effects which are potentially associated with the practices of timber workers in our environment and as such, it is important we determine the workers' awareness of the occupational hazards, effects and safety practices with the intention of highlighting their health education and training needs in order to empower them to take self action in the pursuit of good health and well-being.

\section{Methodology}

\subsection{Study Area}

The survey was conducted in three Local Government Areas (LGA); Owerri North, Orlu and Okigwe LGAs where the three major timber markets are located in Imo State. Imo State is located in the South Eastern part of Nigeria, within longitude $5^{\circ} 29^{\prime} 06^{\prime \prime} \mathrm{N}$ and latitude $7^{\circ} 02^{\prime} 06^{\prime \prime} \mathrm{E}$ occupying an area between the lower river Niger and the upper and middle Imo River. According to the 2006 census, Imo State had a population of 3.93 million (2.03 million males and 1.9 million females) occupying an area of 5183 square kilometers with Okigwe LGA having a population of 132,701 occupying 324 square kilometers, Orlu LGA having a population of 142,792 occupying 133 square kilometers and Owerri North LGA having a population of 176,334 occupying 220 square kilometers [15] [16].

\subsection{Study Population/Study Design/Selection Criteria}

The study population comprised all timber shed owners and their apprentices (timber workers) involved in the 
processing and marketing of wood in the three major timber markets in Imo State. The study was a cross sectional descriptive design that involved the total population of 319 timber workers. Inclusion criteria were any individual in the market that owned a timber shed or was an apprentice aged 10 years and above. The exclusion criteria were any selected individual that had an acute illness at the time of the study.

\subsection{Data Collection and Analysis}

Three hundred and nineteen pretested semi structured questionnaires were interviewer administered and data was collected from all the participants.

The questionnaire comprised 4 sections, section one: sociodemographic characteristics; section two: awareness and effects of occupational hazards; section three: attitude towards safety practices and section four: safety and hygienic practices when handling wood. Medical students were recruited for the administration of the questionnaires. The returned questionnaires were checked for errors, cleaned, validated manually and analyzed. Descriptive statistics (frequency tables and summary indices) were generated.

\subsection{Ethical Considerations}

Permission was sought from the timber associations to conduct the survey and verbal consents were given by the respondents. Ethical approval was obtained from the Ethics Committee of Imo State University Teaching Hospital Orlu.

\section{Results}

Three hundred and nineteen questionnaires were administered and all were completed and returned.

\subsection{Sociodemographic Characteristics}

More than half of the respondents $(65.3 \%)$ were between the ages of 20 and 39 years with the majority, male $(95.9 \%)$, married $(61.8 \%)$ and most of them $(93.1 \%)$ with either a primary or secondary school level of education. Most of the respondents $(89.3 \%)$ received apprenticeship training in wood processing and marketing and had been on the job for up to 20 years $(87.5 \%)$ with less than one third (30.1\%) still undergoing apprenticeship (Table 1).

\subsection{Knowledge and Attitude of Respondents}

Majority of the respondents who were aware of the hazardous nature of wood dust (95.9\%) reported that their sources of awareness were mainly from personal experience (54.6\%) and during training (34\%) and least from health education programs (3.9\%). The effects of the occupational hazards encountered were mainly nose, throat irritation and cough (32.9\%) and eye irritation and itching (21.9\%) and the least was skin infection (2.9\%). Although the majority of respondents were of the opinion that it was necessary to always protect oneself while working (85.6\%); and that the hand glove (38.2\%) followed by the coat overall $(24.8 \%)$ were the most important PPE to use, only about $3.8 \%$ of the respondents and none of the respondents mentioned face mask and respirators respectively as the most important PPE. While the majority of the respondents (40.4\%) were of the opinion that sweeping dusty floors were associated with the occupational hazard effects encountered, only $9.7 \%$ and $8.8 \%$ were of the opinion that not using a particular PPE and scattering work tools respectively were also associated with the hazard effects encountered (Table 2).

\subsection{Safety and Hygienic Practices of Respondents}

The majority of the respondents reported the use of PPE (87.1\%) with hand gloves being the most used form of PPE (69.4\%) followed by coat overalls (27.3\%). However, only $12.9 \%$ of those that have ever used PPE, and always use them; and the reasons for not using PPE were either due to forgetfulness (38\%), affordability (34.3\%), inconvenience (30.6\%) and not being a necessity (28.9\%). Close to half of the respondents (47\%) did not sprinkle water on wood before sawing in order to reduce dust. In the event of fire or injury, none of the workshops had a fire extinguisher and most of them did not have or use first aid box (99.1\%) but receive treatment when injured or ill from the chemist $(70.2 \%)$. With respect to hygiene, all the respondents indiscriminately 
Table 1. Sociodemographic characteristics.

\begin{tabular}{|c|c|c|}
\hline Variable & Category & Frequency $(\%)$ \\
\hline \multirow{6}{*}{ Age } & $10-19$ & $18(5.6)$ \\
\hline & $20-29$ & $93(29.2)$ \\
\hline & $30-39$ & $115(36.1)$ \\
\hline & $40-49$ & $52(16.3)$ \\
\hline & 50 and above & $41(12.9)$ \\
\hline & Total & $319(100)$ \\
\hline \multirow{3}{*}{ Gender } & Male & $306(95.9)$ \\
\hline & Female & $13(4.1)$ \\
\hline & Total & $319(100)$ \\
\hline \multirow{4}{*}{ Marital Status } & Married & $197(61.8)$ \\
\hline & Single & $99(31.0)$ \\
\hline & Others & $23(7.2)$ \\
\hline & Total & $319(100)$ \\
\hline \multirow{4}{*}{ Educational Status } & None & $22(6.9)$ \\
\hline & Primary & $195(61.1)$ \\
\hline & Secondary & $102(32.0)$ \\
\hline & Total & $319(100)$ \\
\hline \multirow{3}{*}{ Work Status } & Master & $223(69.9)$ \\
\hline & Apprentice & $96(30.1)$ \\
\hline & Total & $319(100)$ \\
\hline \multirow{6}{*}{ Duration on the job (yrs) } & $<1$ & $24(7.5)$ \\
\hline & $1-10$ & $145(45.5)$ \\
\hline & $11-20$ & $110(34.5)$ \\
\hline & $21-30$ & $26(8.2)$ \\
\hline & $>30$ & $14(4.4)$ \\
\hline & Total & $319(100)$ \\
\hline \multirow{3}{*}{ Received Training } & Yes & $285(89.3)$ \\
\hline & No & $34(10.7)$ \\
\hline & Total & $319(100)$ \\
\hline \multirow{4}{*}{ Residence } & Owerri North & $141(44.2)$ \\
\hline & Orlu & $122(38.2)$ \\
\hline & Okigwe & $56(17.6)$ \\
\hline & Total & $319(100)$ \\
\hline
\end{tabular}

disposed of wood waste and most of them (88.4\%) ate inside the workshop while work was going on. Though a majority washed their hands before eating $(75.6 \%)$, they did not use their hands to eat at work $(82.8 \%)$. However, about one third of the respondents $(33.2 \%)$ did not have a bath after work each day (Table 3 ).

\section{Discussion}

This study determined the awareness of occupational hazards, the effects, safety and hygienic practices of timber 
Table 2. Knowledge and attitude of respondents.

\begin{tabular}{|c|c|c|}
\hline Variable & Category & Frequency $(\%)$ \\
\hline \multicolumn{3}{|l|}{ KNOWLEDGE } \\
\hline \multirow{2}{*}{$\begin{array}{l}\text { Aware of the occupational hazard } \\
\qquad(\mathrm{n}=319)\end{array}$} & Yes & $306(95.9)$ \\
\hline & No & $13(4.1)$ \\
\hline \multirow{4}{*}{$\begin{array}{l}\text { "Source of awareness of the occupational } \\
\text { hazard }(n=306)\end{array}$} & Personal experience & $167(54.6)$ \\
\hline & During training & $104(34.0)$ \\
\hline & Colleagues & $36(11.8)$ \\
\hline & Health education & $12(3.9)$ \\
\hline \multirow{7}{*}{$\begin{array}{l}\text { "Effects of the occupational hazards } \\
\text { encountered }(n=306)\end{array}$} & Nose/throat-irritation/cough & $110(35.9)$ \\
\hline & Eye irritation/itching & $67(21.9)$ \\
\hline & Bruises/cuts/injury & $57(18.6)$ \\
\hline & Back/waist pain & $37(12.1)$ \\
\hline & Fatigue/exhaustion & $20(6.5)$ \\
\hline & Slips/falls & $19(6.2)$ \\
\hline & Skin infections & $9(2.9)$ \\
\hline \multicolumn{3}{|l|}{ ATTITUDE } \\
\hline \multirow{2}{*}{$\begin{array}{l}\text { Do you feel the necessity to always } \\
\text { protect yourself while working }(n=319)\end{array}$} & Yes & $273(85.6)$ \\
\hline & No & $46(14.4)$ \\
\hline \multirow{8}{*}{$\begin{array}{l}\text { Single most important PPE you feel that } \\
\text { is important }(n=319)\end{array}$} & Hand gloves & $122(38.2)$ \\
\hline & Coat overalls & $79(24.8)$ \\
\hline & Eye goggles & $48(15.1)$ \\
\hline & Helmets & $24(7.5)$ \\
\hline & Boots & $21(6.6)$ \\
\hline & Earplugs/muffs & $13(4.1)$ \\
\hline & Face masks & $12(3.8)$ \\
\hline & Respirators & $0(0)$ \\
\hline \multirow{7}{*}{$\begin{array}{c}\text { "What work behavior or action do } \\
\text { you feel is associated with the effects } \\
\text { encountered }(n=319)\end{array}$} & Dry sweeping dusty floors & $129(40.4)$ \\
\hline & Working in bad postures & $64(20.1)$ \\
\hline & Emptying dust filter bags & $37(11.6)$ \\
\hline & Hand sanding & $34(10.7)$ \\
\hline & Not using PPE & $31(9.7)$ \\
\hline & Scattering work tools & $28(8.8)$ \\
\hline & Compressed air to dislodge dust & $16(5.0)$ \\
\hline
\end{tabular}

${ }^{*}$ multiple responses.

workers in Imo, a South Eastern State in Nigeria. In the present study, the timber workers were predominantly male within the age group of 20 - 49 years although a majority appeared to be below 40 years which is not unusual, as the work requires a high degree of physical manual labour more effectively carried out by younger adults; and this has been similarly observed in a study in Ghana and in other Nigerian studies [17]-[19]. In a study in Calabar, Nigeria by Osuchukwu et al., it was observed, that the timber workers were predominantly male but the majority appeared to be above 40 years [20]. 
Table 3. Safety and hygienic practices of respondents.

\begin{tabular}{|c|c|c|}
\hline Variable & Category & Frequency (\%) \\
\hline \multicolumn{3}{|l|}{ SAFETY PRACTICES } \\
\hline \multirow{2}{*}{$\begin{array}{l}\text { Use of Personal Protective Equipment } \\
\qquad(n=319)\end{array}$} & Yes & $278(87.1)$ \\
\hline & No & $41(12.9)$ \\
\hline \multirow{8}{*}{$\begin{array}{c}\text { "Form of Personal Protective Equipment } \\
\text { used }(n=278)\end{array}$} & Hand gloves & $193(69.4)$ \\
\hline & Coat overalls & $76(27.3)$ \\
\hline & Eye goggles & $39(14.0)$ \\
\hline & Helmets & $31(11.2)$ \\
\hline & Face masks & $22(7.9)$ \\
\hline & Boots & $19(6.8)$ \\
\hline & Earplugs/muffs & $9(3.2)$ \\
\hline & Respirators & $0(0)$ \\
\hline \multirow{3}{*}{$\begin{array}{l}\text { Frequency of Personal Protective } \\
\text { Equipment use }(\mathrm{n}=\mathbf{2 7 8})\end{array}$} & Always & $36(12.9)$ \\
\hline & Sometimes & $187(67.3)$ \\
\hline & Rarely & $55(19.8)$ \\
\hline \multirow{4}{*}{$\begin{array}{l}\text { Reasons why PPE are not always used } \\
\qquad(\mathrm{n}=\mathbf{2 4 2})\end{array}$} & Forget to use & $92(38.0)$ \\
\hline & Can't afford it & $83(34.3)$ \\
\hline & Inconvenient & $74(30.6)$ \\
\hline & Not a necessity & $70(28.9)$ \\
\hline \multirow{2}{*}{$\begin{array}{l}\text { Sprinkle water before sawing wood } \\
\qquad(\mathrm{n}=319)\end{array}$} & Yes & $169(53.0)$ \\
\hline & No & $150(47.0)$ \\
\hline \multirow{2}{*}{$\begin{array}{l}\text { Availability and use of first Aid box } \\
\qquad(n=319)\end{array}$} & Yes & $3(0.9)$ \\
\hline & No & $316(99.1)$ \\
\hline \multirow{4}{*}{$\begin{array}{l}\text { Source of treatment when sick or injured } \\
\qquad(n=319)\end{array}$} & Chemist & $224(70.2)$ \\
\hline & Self medication & $48(15.1)$ \\
\hline & Hospital & $26(8.2)$ \\
\hline & Native treatment & $21(6.6)$ \\
\hline \multirow{2}{*}{$\begin{array}{l}\text { Fire Extinguisher } \\
\quad(\mathrm{n}=\mathbf{3 1 9})\end{array}$} & Present & $0(0)$ \\
\hline & Absent & $319(100)$ \\
\hline \multicolumn{3}{|l|}{ HYGIENIC PRACTICES $(n=319)$} \\
\hline \multirow{2}{*}{ Eating inside workshop } & Yes & $282(88.4)$ \\
\hline & No & 37 (11.6) \\
\hline \multirow{2}{*}{ Use of hand to eat at work } & Yes & $55(17.2)$ \\
\hline & No & $264(82.8)$ \\
\hline \multirow{2}{*}{ Wash hands before eating } & Yes & $241(75.6)$ \\
\hline & No & $78(24.4)$ \\
\hline \multirow{2}{*}{ Bath after work each day } & Yes & $213(66.8)$ \\
\hline & No & $106(33.2)$ \\
\hline \multirow{2}{*}{ Indiscriminate disposal of waste wood } & Yes & $319(100)$ \\
\hline & No & $0(0)$ \\
\hline
\end{tabular}

${ }^{*}$ multiple responses. 
The timber workers in the present study, mostly had either a primary or secondary school level of education which was also observed in other studies [17] [19] and this could be explained by the fact that, some level of training and skill is required in the processing and marketing of wood as seen in the present study, where about $30 \%$ of the respondents were apprentices.

The level of awareness of occupational hazards observed in the present study could be explained to some degree by the level of education and also, the length of work experience observed in the majority of the respondents, where over $80 \%$ had been on the job for at least one year. A number of other studies [21]-[25] also observed this high level of awareness but Mitchual et al. [22] reported that the high level of awareness was irrespective of their educational background and probably due to the length of work experience. Also, Sabitu et al. [23], though among welders, reported other reasons for high awareness such as institutional training and institutional adaptation of safety regulatory measures. On the contrary, Osagbemi et al. [26], in the Northern part of Nigeria, reported a generally low level of awareness of occupational hazards except for electric shock, and that their source of information for safety measures were mainly from their employers; although, more than one third of the respondents had no source of information, there was still a majority of the respondents that were aware of the need for safety measures.

In the present study, their sources of information of occupational hazards and safety measures were mainly from personal experiences and training which was similar to the study by Osuchukwu et al. [20], where personal effort and on the job training were attributed as the main sources of awareness of occupational health and safety, and also Faremi et al. [19], attributed the main sources of information to seminars, friends and colleagues.

The effects of the hazards encountered by the respondents in the present study were mainly upper respiratory symptoms, eye symptoms, external injuries and body pain which are consistent with studies involving timber work [17]-[21] [25] [26]. These observed effects were mainly reported by the respondents as caused by their work behaviour and actions of dry sweeping dusty floors, working in bad postures, emptying dust filter bags and hand sanding. In spite of the fact that they knew inhalation of wood dust is hazardous, close to half of the respondents in the present study did not engage in dust reducing safety practices like sprinkling water on wood surfaces before sawing it. Also surprisingly, about $90 \%$ of the respondents did not know that not using a particular PPE was associated with the effects encountered, even when a majority felt the necessity to always protect self while working.

The respondents' knowledge of the effect of the hazards encountered, appeared not to have positively influenced either their safety practices or their opinion on the type of PPE they felt is the most important as the majority of the respondents felt that the hand gloves, coat overalls and eye goggles in that order, were the most singularly important PPE; the face masks and the respirators needed to protect against the commonly experienced upper respiratory symptoms by the respondents, were considered the least singularly most important PPE, as none of the respondents even reported the respirator as important.

Furthermore, though it was observed that a majority of the respondents reported that they use PPE, it was only $13 \%$ of them that always used PPE. Nevertheless, the PPE mainly used, was the hand gloves followed by coat overalls which was only used by $27 \%$ of the respondents. So it is obvious, that there were poor safety practices in the present study exemplified by the total absence of fire extinguishers, lack and non-use of first aid boxes by $99 \%$ of the respondents and the use of hospitals in the event of injuries and illnesses by only $8 \%$ of the respondents. This lack of safety practices compound the consequences of the low prevalence of correct and consistent use of PPE amongst the timber workers and this low prevalence especially in developing countries has consistently been reported in previous studies [17]-[19] [21] [22] [25] [26].

The reasons attributed for the non-consistent and correct use of PPE were essentially similar; though, varied slightly from study to study. Studies from Ghana by Ochire-Boadu et al. [17], reported inadequate supply and discomfort as reasons for the low use of PPE; and also, Mitchual et al. [22], reported on one hand, the unwillingness to wear face shields probably due to discomfort and on the other hand, a willingness to wear hand gloves and coat overalls probably influenced by their awareness of the need to wear them in order to protect themselves during wood processing. Studies from Nigeria by Faremi et al. [19] reported forgetfulness, inconvenience and not being a necessity as reasons for not using PPE; and also, Osagbemi et al. [26], reported nonavailability, not being a necessity, forgetfulness and inconvenience as reasons for non-use of PPE. These observations were similar to that observed in the present study, where the lack of use was also attributed to forgetfulness, non-availability due to affordability, inconvenience and not being a necessity.

The hygienic practices of the timber workers appeared to be generally poor, where more than three quarters of 
the respondents ate inside their workshops, about one quarter of the respondents did not wash hands before eating, about one third of the respondents did not take a bath after work each day and also, where all the respondents indiscriminately disposed of waste wood. These practices further increase the risk of diseases and accidents in the work place as occupational illnesses normally develop over a period of time because of the poor hygiene and sanitary conditions of the work environment.

The proper disposal of waste wood and the maintenance of proper hygienic and sanitary conditions remains a major challenge facing the timber industry, probably associated with cultural attitudes, as the existing guidelines for the proper disposal and treatment are not complied with; not because there are no laws or the timber workers are ignorant but due to the fact that the Sanitary and Environmental regulatory agencies charged with the responsibility of enforcing the laws are inactive [27].

\section{Conclusion}

Timber workers in our environment are faced with increased risks of diseases and accidents and also the challenges of protection and safety. Despite their high awareness of occupational hazards, the timber workers have not associated the effects of the hazards they generally experience to the specific lack of consistent use of the appropriate PPE and as such, they remain continuously exposed to the risk of accidents and diseases especially the upper respiratory illnesses which appear to be their predominant complaint. Consequently, there is need for proper education of the relevant hazards, their associated PPE, hygienic practices and consistent use of the different protective devices. Therefore, the introduction and enforcement of safety health measures through training and regular inspection by the relevant agencies will help to further promote the adoption of safety and hygienic practices among timber workers in order to safe-guard and maintain good health and wellbeing among the workers.

\section{Acknowledgements}

We thank the timber associations and the participants that agreed to be part of this research and also the research assistants: Esenwah Alexandra and Anyanwu Sandra who helped in the data collection.

\section{Authors' Contributions}

All the authors participated in the study.

\section{Conflict of Interests}

The authors hereby declare that there is no conflict of interests.

\section{Funding}

There was no external source of funding.

\section{References}

[1] World Health Organization (WHO) (1986) Detection of Occupational Diseases. WHO, Geneva.

[2] Packard, R.M. (1989) Industrial Production; Health and Disease in Sub-Saharan Africa. Social Science \& Medicine, 28, 75-96. http://dx.doi.org/10.1016/0277-9536(89)90102-0

[3] Aliyu, A.A. and Shehu, A.U. (2006) Occupational Hazards and Safety Measures among Stone Quarry Workers in Northern Nigeria. Nigerian Medical Practice, 50, 42-47.

[4] Asuzu, M.C. (1994) Occupational Health. A Summary Introduction and Outline of Principles. African Link Books, Ibadan.

[5] Toscano, G., Jack, T. and Ben, V. (1996) Occupational Injury Fatalities. Statistical Bulletin Metropolitan Life Insurance Company, 77, 12-22.

[6] Steen, T.W., Gyi, K.M., White, N.W., et al. (1997) Prevalence of Occupational Lung Disease among Botswana Men Formerly Employed in the South African Mining Industry. Occupational and Environmental Medicine, 54, 19-26. http://dx.doi.org/10.1136/oem.54.1.19

[7] Magauzi, R., Mabaera, B., Rusakaniko, S., et al. (2011) Health Effects of Agrochemicals among Farm Workers in 
Commercial Farms of Kwekwe District, Zimbabwe. The Pan African Medical Journal, 9, 26. http://dx.doi.org/10.4314/pamj.v9i1.71201

[8] Siziya, S., Rudatsikira, E., Mweemba, A., et al. (2013) Exposure to Occupational Health Hazards among Zambian Workers. Occupational Medicine, 63, 109-115. http://dx.doi.org/10.1093/occmed/kqs201

[9] Bio, F., Sadhra, S., Jackson, C. and Burge, P. (2007) Low Back Pain in Underground Gold Miners in Ghana. Ghana Medical Journal, 41, 21-25.

[10] Birabi, B.N., Dienye, P.O. and Ndukwu, G.U. (2012) Prevalence of Low Back Pain among Peasant Farmers in a Rural Community in South Nigeria. Rural and Remote Health, 12, 1920.

[11] World Health Organization (WHO) (1998) The World Health Report 1998 - Life in the 21st Century: A Vision for All. Geneva, WHO, 95-96.

[12] Omokhodion, F. (2009) Occupational Health in Nigeria. Occupational Medicine (London), 59, 201. http://dx.doi.org/10.1093/occmed/kqn110

[13] Eroke, L. (2013) Nigeria: Promoting Health and Safety of Employees in the Workplace. All Africa Archive. http://allafrica.com/stories/201304290122.html

[14] Bean, T.L. and Butcher, T.W. (2006) Wood Dust Exposure Hazards. Environment and Health AEX-595.1-2006 (Revised). http://healthfully.org/eoh/id1.html

[15] Federal Republic of Nigeria, National Population Commission (2010) 2006 Population and Housing Census Priority Table. Volume 3, Population Distribution by Sex. State, LGA and Senatorial District, Abuja.

[16] Government of Imo State (2006) Statistical Year Book: Imo State Planning and Economic Development Commission. Owerri.

[17] Ochire-Boadu, K., Kusi, E. and Lawer, E.A. (2014) Occupational Hazards and Safety Practices: A Concern among Small Scale Sawmilling Industries in Tamale Metropolis, Ghana. International Journal of Scientific \&Technology Research, 3, 234-236.

[18] Uhumwangho, O.M., Njinaka, I., Edema, O.T., Dawodu, O.A. and Omoti, A.E. (2010) Occupational Eye Injury among Sawmill Workers in Nigeria. Asian Journal of Medical Sciences, 2, 233-236.

[19] Faremi, F.A., Ogunfowokan, A.A., Mbada, C., Olatubi, M.I. and Ogungbemi, A.V. (2014) Occupational Hazard Awareness and Safety Practices among Nigerian Sawmill Workers. International Journal of Medical Science and Public Health, 3, 1244-1248. http://dx.doi.org/10.5455/ijmsph.2014.260620142

[20] Osuchukwu, N.C., Osuchukwu, E.C., Eko, J.E. and Otareh, O. (2015) Occupational Exposure to Wood Dust in Calabar Municipality, Cross River State, Nigeria. International Journal of Science and Research (IJSR), 4, 1414-1420.

[21] Adeoye, O.A., Adeomi, A.A., Abodunrin, O.L., Olugbenga-Bello, A. and Abdulsalam, S.T. (2015) Awareness of Occupational Hazards and Health Problems among Sawmill Workers in Osun State, Nigeria. International Journal of Research \& Review, 2, 1-14.

[22] Mitchual, S.J., Donkoh, M. and Bih, F. (2015) Awareness and Willingness to Utilize Health and Safety Measures among Woodworkers of a Timber Processing Firm in Ghana. Journal of Scientific Research \& Reports, 6, 178-188. http://dx.doi.org/10.9734/JSRR/2015/15786

[23] Sabitu, K., Iliyasu, Z. and Dauda, M. (2009) Awareness of Occupational Hazards and Utilization of Safety Measures among Welders in Kaduna Metropolis, Northern Nigeria. Annals of African Medicine, 8, 46-51. http://dx.doi.org/10.4103/1596-3519.55764

[24] Kwankye, E.A. (2012) Worker Characteristics and Compliance to Occupational Health and Safety. A Study of Naja David Wood Industry Limited in Kumasi Metropolis. A Thesis Submitted to the Department of Sociology and Social Work, Kwame Nkrumah University of Science and Technology, Kumasi.

[25] Fatusi, A. and Erhabor, G. (1996) Occupational Health Status of Sawmill Workers in Nigeria. Journal of the Royal Society of Health, 116, 232-236. http://dx.doi.org/10.1177/146642409611600408

[26] Osagbemi, G.K., La-Kadri, R.T. and Aderibigbe, S.A. (2010) In a Study on the "Awareness of Occupational Hazards, Health Problems and Safety Measures among Sawmill Workers in North Central Nigeria. TAF Preventive Medicine Bulletin, 9, 325-328.

[27] Ogunbode, E.B., Fabunmi, F.O., Ibrahim, S.M., Jimoh, I.O. and Idowu, O.O. (2013) Management of Sawmill Wastes in Nigeria: Case Study of Minna, Niger State. Greener Journal of Science, Engineering and Technology Research, 3 , $34-41$. 


\section{Submit or recommend next manuscript to SCIRP and we will provide best service for you:}

Accepting pre-submission inquiries through Email, Facebook, LinkedIn, Twitter, etc.

A wide selection of journals (inclusive of 9 subjects, more than 200 journals)

Providing 24-hour high-quality service

User-friendly online submission system

Fair and swift peer-review system

Efficient typesetting and proofreading procedure

Display of the result of downloads and visits, as well as the number of cited articles

Maximum dissemination of your research work

Submit your manuscript at: http://papersubmission.scirp.org/ 